\title{
Effects of cassava flour on the stickiness properties of wheat bread dough: unleavened, leavened and frozen dough
}

\author{
Shadrack Mubanga CHISENGA ${ }^{1,2}$, Tilahun Seyoum WORKNEH ${ }^{1}$, Geremew BULTOSA ${ }^{3}$, Buliyaminu \\ Adegbemiro ALIMI ${ }^{1}$
}

Received February 07, 2019; accepted July 29, 2019.

Delo je prispelo 07. februarja 2019, sprejeto 29. julija 2019.

Effects of cassava flour on the stickiness properties of wheat bread dough: unleavened, leavened and frozen dough

Abstract: Cassava utilization in the form of cassava-wheat bread is increasing in Africa. However, information on stickiness properties of dough handling under normal and frozen conditions is limited. In view of this the gluten contents and water absorption of doughs, and stickiness of unleavened, leavened and leavened-frozen doughs processed from 0 to $30 \%$ cassava flour substitution level (CFSL) as compared to wheat flour were determined. The gluten contents of flour blends $(6.88-13.00 \%)$ decreased significantly $(p<0.05)$ with increasing CFSL. Water absorption capacity (WAC) was ranged from $59.57-61.70 \%$ and showed positive correlation with gluten contents $(\mathrm{r}=0.595, p<0.05)$. Cassava variety $(\mathrm{CV})$ and CFSL had significant $p<0.05)$ influence on stickiness of unleavened (34.14-122.17 g), leavened (13.53-83.94 g) and leavened frozen (126.88-146.82 g) dough. Irrespective of CV and CFSL, frozen dough had the highest stickiness. Gluten content and WAC had significant $(p<0.01)$ negative influence on stickiness in unleavened $(r=-0.445$ and -0.437 , respectively) and leavened $(r=$ -0.457 and -0.434 , respectively) doughs. The variation in stickiness was influenced by gluten contents and CFSL. The unfrozen dough and frozen dough exhibited higher stickiness in lower and higher gluten content flour blends, respectively.

Key words: cassava; composite flours; gluten; stickiness; wheat
Učinki tapioke na lepljivost pšeničnega krušnega testa: nevzhajano, vzhajano in zmrznjeno vzhajano testo

Izvleček: Uporaba tapioke, škroba pridobljenega iz manioke (kasave) (Manihot esculenta Crantz) narašča v obliki priprave mešanega kruha s pšenico na afriški celini, a je kljub temu zelo malo podatkov o lepljivosti navadnega in zmrznjenega testa. $\mathrm{V}$ povezavi s tem je bila glede na vsebnost glutena in absorpcijo vode v testu določena leplivost nevzhajanega, vzhajanega in zmrznjenega vzhajanega testa, narejenega iz mešane moke, v keteri so pšenično moko nadomestili z od 0 do $30 \%$ tapioke (CFSL)v primerjavi s testom iz čiste pšenične moke. Vsebnost glutena je $\mathrm{v}$ mešanicah moke značilno upadala $\mathrm{z}$ naraščanjem dodatka tapioke $(6,88-13,00 \% ; p<0,05)$. Sposobnost absorbcije vode (WAC) je bila v območju od 59,57 do 61,70\% in je pokazala pozitivno korelacijo $\mathrm{z}$ vsebnostjo glutena $(\mathrm{r}=$ $0,595, p<0,05)$. Sorta manioke $(\mathrm{CV})$ in delež tapioke $\mathrm{v}$ mešani moki (CFSL) sta imela značilen učinek $(p<0,05)$ na lepljivost nevzhajanega $(34,14-122,17 \mathrm{~g})$, vzhajanega $(13,53-83,94 \mathrm{~g})$ in vzhajanega zmrznjenega testa (126,88-146,82 g). Ne glede na CV in CFSL je imelo vzhajano zmrznjeno testo največjo lepljivost. Vsebnost glutena in WAC sta imeli značilni negativni učinek $(p<0,01)$ na lepljivost nevzhajanega $(r=-0,445$ in $-0,437)$ in vzhajanega testa $(\mathrm{r}=-0,457$ in $-0,434)$. Na spremenljivost lepliivosti testa sta vplivali vsebnost glutena in CFSL. Nezmrznjena in zmrznjena testa so pokazala večjo lepljivost pri manjših in večjih vsebnostih glutena v mešanicah moke.

Ključne besede: manioka; sestavljene moke; gluten; lepljivost; pšenica

1 University of Kwazulu-Natal, Department of Bioresources Engineering, Carbis Road, Rabie Saunders Building Scottsville, South Africa

2 Corresponding author, e-mail: 216075862@stu.ukzn.ac.za, mubanga.chisenga@live,com

3 Botswana University of Agriculture and Natural Resources, Department of Food Science and Technology, Gaborone, Botswana 


\section{INTRODUCTION}

Stickiness, a surface related property, is a tendency of dough to adhere to contact surface of equipment and hands during mixing and kneading. This tendency affect dough handling (Villanueva et al., 2018). Moreover, sticky dough is considered a problem to high speed mixing, and can cause disruption to production schedule, and subsequent loss of quality. Stickiness is associated with physical factors such adhesive force, combined effects of adhesive and cohesive forces (Hoseney and Smewing, 1999; Král et al., 2018) and viscoelasticity.

Stickiness properties of dough are influenced by several factors. The most important are extent of mixing and water quantity (Ahmed and Thomas, 2018). However, studies have shown that excessive water plays the most significant role in dough stickiness. Water acts as plasticizer in dough system due to its influence on molecular mobility (Liu et al., 2018a). Some properties of dough such as surface tension and solvation are dependent on the plasticizing effect of water (Fonseca-Florido et al., 2018). Constituents of food systems such as proteins, in particular, glutenin and gliadins (Stone et al., 2018), alpha-amylase activity (Zadeike et al., 2018), and proteolytic enzyme activity (Zadeike et al., 2018) are also reported to affect stickiness of dough. Therefore, information on the water absorption capability and intrinsic composition of base material is necessary to estimate the stickiness of resulting dough.

Compressive force is applied during mixing of ingredients to form dough and kneading of resulting dough. Force of adhesion between the contact surface and dough may result in stickiness depending on the strength and cohesion forces of the dough. Stickiness has been reported to be dependent on the rheological properties of the dough. Grausgruber et al. (2003) proposed that if the dough is strong and elastic, the adhesive force is overcome, and the dough will separate from the surface (i.e., the dough is not sticky). On the other hand, if the dough is viscous, it will flow and not overcome the adhesive force (i.e. the dough is sticky). Therefore, understanding the stickiness properties of dough from a formulation is important for its handling and machination. In this regard scientific report on the stickiness properties of composite wheat-cassava flour dough is virtually absent.

Rheological tests on doughs are used as quality indicators of the gluten and starch polymers molecular structure in ascertaining the dough's functional behavior. The viscoelastic network of the dough is dependent on gluten development properties during mixing of wheat flour, and can influence the handling characteristics of dough during processing. The inclusion of cassava flour into wheat flour in bread making is an important issue in the sustainable utilization of cassava. Increasing acceptance of bread from composite cassava-wheat flour would stir interest in the storage of the composite flour dough through freezing. However, frozen storage of the dough could have additional effect on its subsequent handling and machination during bakery process. Cassava flour consists mainly of starches and some minor amounts of fibres. In dough system, starches impart high water binding capacity (Kaushik et al., 2015) but favours more starch-starch interaction than wheat gluten proteinprotein. Thus, incorporation of cassava flours in frozen wheat dough system may lead to reduced gluten network deteriorations and ameliorate the rate of ice crystal formation during freezing which are detrimental and contribute to gluten network disruptions. However, there is limited information on dough stickiness characteristics in the cassava-wheat frozen dough system. Also, baking ingredients such as yeast, sugar, salt, and fat can influence stickiness of dough. Differences in chemical constituents and flour particle size (Sakhare et al., 2014) can affect the stickiness of the dough. Ascertainable stickiness based purely on raw material and water, and subsequently on developed dough is a reflection of industrial quality acceptance criteria based on raw material. In the present article, stickiness measurements were conducted on three doughs: (1) dough made from mixture of flour and water, (2) developed dough with ingredients, and (3) frozen developed dough. The hypothesis: (1) stickiness of the wheat dough decreases with increasing percentage of cassava flour concentration and (2) there is a variation in stickiness of the three different doughs.

\section{MATERIALS AND METHODS}

\subsection{SOURCE OF MATERIALS}

The wheat flour (white flour, Golden Cloud, Pietermartzburg, South Africa) was obtained from the South African market. Six cassava varieties (Bangweulu, Katobamputa, Mweru, Kariba, Kampolombo and Chila) were planted at Mansa Root and Tuber Research Station, a branch of Zambian Agriculture Research Station (ZARI), Mansa District, Luapula Province, Zambia. They were harvested from each block after 18 months of planting.

\subsection{CASSAVA FLOUR}

The cassava roots were processed into flour using the method of Eriksson et al. (2014). The particle size dis- 
tribution at $90 \%$ (D90) finer particles of cassava flours was determined as described in Patwa et al. (2014).

\subsection{BLENDING OF WHEAT-CASSAVA FLOUR}

Three levels of wheat: cassava (90:10, 80:20, 70:30) composite flours were prepared as described in Aboaba and Obakpolor (2010). Wheat flour (100\%) was used as a control in the analysis.

\subsection{CHEMICAL ANALYSIS}

Protein content was determined as described in Nuwamanya et al. (2010) using the Dumas combustion method of nitrogen content analysis (Leco Truspec Model FP-528, St Joseph Mi, USA). Percentage protein was calculated as $\% \mathrm{~N}$ x 6.25. The moisture, lipid and fibre contents were determined as described in (AOAC, 2012) methods 925.10, 920.39 and 962.09 , respectively. The amylose content was determined using a Megazyme amylose/amylopectin assay kit (K-AMYL 12/16 Megazyme International, Ireland). The gluten content was determined by hand washing method using $2 \%$ sodium chloride solution by taking about $10 \mathrm{~g}$ flour sample as described in (AACC, 2011) Method 38-10. Water absorption capacity was determined with Brabender Farinograph (Model 820603, Brabender OHG, Duisberg, Germany) at $30 \pm 0.2^{\circ} \mathrm{C}$

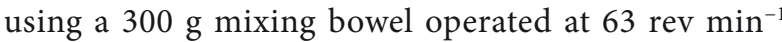
according to AACC (2011) Method 54-21 of constant dough mass method.

\subsection{DOUGH PREPARATION}

The unleavened dough (flour and water only) was prepared as described in Grausgruber et al. (2003) with modification. A $20 \mathrm{~g}$ flour was mixed with water at absorption rates from Farinogram. The mixture was kneaded until the dough was formed. The leavened dough (250 g wheat flour, $25 \mathrm{~g}$ sugar, $3 \mathrm{~g}$ salt, $5 \mathrm{~g}$ baking fat and $2.5 \mathrm{~g}$ baker's yeast) was produced from white bread wheat flour dough baking method as described in AACCI (2000) Method 10 to 10.03. The formed dough was divided into portions of $20 \mathrm{~g}$. Then the portions were subjected to freezing with air temperature in convection at $-40{ }^{\circ} \mathrm{C}$ for 35 min until the geometric dough centre reached $-18{ }^{\circ} \mathrm{C}$. After freezing, the doughs were wrapped in polyethylene plastic bags and stored at frozen temperature of $-18{ }^{\circ} \mathrm{C}$ for three weeks.

\subsection{STICKINESS OF DOUGHS}

Dough stickiness was determined according to the procedure of Sangnark and Noomhorm (2004) using a Texture Analyzer (TA-XT2, Stable Micro Systems Ltd., England) using $5 \mathrm{~g}$ dough for each test. The adhesive test was evaluated at speed $0.5 \mathrm{~mm} \mathrm{~s}^{-1}$, and post-test speed $10 \mathrm{~min} \mathrm{~s}^{-1}$ with a $25 \mathrm{~mm}$ perspex cylinder probe at applied force of $80 \mathrm{~g}(0.785 \mathrm{~N})$ with trigger type: Button. The recorded parameters were peak positive force, stickiness, work of adhesion, and peak positive area.

\subsection{DATA ANALYSIS}

A completely randomized design comprising of two factors cassava variety and blend ratio (cassava concentration) was used. Triplicate data were analyzed by two-way ANOVA, and Pearson's correlations were performed using GenStat $18^{\text {th }}$ Edition software and mean differences were determined using Fisher's Least Significance Difference (LSD) test at $5 \%$ significant level.

\section{RESULTS AND DISCUSSION}

\subsection{PROXIMATE COMPOSITION OF CASSAVA AND WHEAT FLOURS}

The moisture content of the cassava flours ranged from 10.43 to $11.76 \%$ compared to $13.37 \pm 0.15 \%$ for wheat flour (Table 1). The moisture content of the composite flour blends ranged from 13.13 to $13.83 \%$ (Table 2), and increased with increase in CFSL ( $r=0.37$, $p<0.001)$. The protein content of the cassava flours was in the range $1.21-1.87 \%$ (Table 1). The protein content of the cassava flours was very low compared to that of wheat flour $(11.03 \pm 0.27 \%)$. Wheat flour proteins contain about $85 \%$ gluten proteins (glutenins and gliadins) (Avramenko et al., 2018; Ribeiro et al., 2018), while cassava flour protein is gluten-free (Chakrabarti et al., 2017). The lipid content of cassava flour ranged between 0.15 and $0.63 \%$. The lipid contents in all cassava flour varieties were significantly ( $p 0.05)$ lower than in wheat flour $(1.72 \pm 0.16 \%)$. The lipids reinforce gluten structure through lipid-protein interactions (Avramenko et al., 2018). The fibre content $(0.03-0.60 \%)$ of the cassava flour was significantly $(p<0.05)$ lower than that of the wheat flour $(2.90 \pm 0.10 \%)$. Leavened aerated bread can only be 
baked from wheat flour because of viscoelastic dough making properties of wheat gluten proteins (Ceresino et al., 2018). Blending of cassava flour with wheat flour influences the blended dough rheological properties.

\subsection{PARTICLE SIZE OF CASSAVA VARIETIES AND WHEAT FLOURS}

Cassava varieties flour average particles size ranged from 250.43 - $333.43 \mu \mathrm{m}$ (Table 1 ) and varied among varieties. The highest and the lowest particle size of cassava flour were recorded in 'Bangweulu' and 'Mweru', respectively. The average particle size of the wheat flour was low $(206.67 \pm 6.81 \mu \mathrm{m})$ compared to the particle size of cassava flours. Particle size is influenced by the milling technique applied and inherent hardness differences of wheat grain and cassava flour varieties (Liu et al., 2015). Flour particle size influences water absorption capacity of the flour which can affect dough quality (Wang et al., 2017).

\subsection{AMYLOSE CONTENT}

The amylose contents in cassava varieties were in the range $16.04-26.95 \%$ and for wheat flour was $20.83 \pm 0.45 \%$ (Table 1 ). Similar cassava amylose contents have been reported, 19.50 - $20.30 \%$ (Morante et al., 2016), $22.60 \pm 1.30$ (dos Santos et al., 2018), and $17.06-25.72 \%$ (Liu et al., 2019). The amylose content is the basis of classifying starches into waxy, semi-waxy, normal/regular and high-amylose types when amylose content is $0-2 \%, 3-15 \% 20-35 \%$, and higher than $40 \%$ of the total starch, respectively (Tester et al., 2004; Morante et al., 2016; Botticella et al., 2018). The result shows all the cassava flour varieties including control sample (wheat flour) were generally classified as normal regular starches.

\subsection{GLUTEN CONTENT AND WATER ABSORP- TION CAPACITY}

The dry gluten content of the wheat sample was $13.00 \pm 0.87 \%$ (Table 2), and decreased with increased CFSL ( $r=-0.839, p<0.05)$. The gluten content followed a decreasing trend as cassava flour addition increased. Thus gluten at $30 \%$ CFSL $<20 \%$ CFSL $<10 \%$ CFSL < Control. However, higher cassava flour inclusion $(30 \%$ CFSL) favored more starch-starch interaction than protein-protein which possibly limits gluten development resulting in weak structures and thus varied recovery of gluten among the varieties. Gluten positively correlated with protein content $(\mathrm{r}=0.703, p<0.05)$. The mixing of wheat flour with water transforms gluten proteins (gliadins and glutenin) into viscoelastic gluten structures, that ultimately determines the quality of the dough and final bread product (Sissons and Smit, 2018). Cassava flour has no gluten type proteins as found in wheat and hence has a diluent effect against a wheat gluten development. Similar was observed in Collar and Armero (2018). Inclusion of cassava flour favours more starchstarch interaction which decreases migration of water to proteins resulting in weak gluten structure. Flour particle size had a significant negative correlation $(r=-0.53$, $p<0.05)$ with gluten development implying that smaller particles hydrate faster and thereby promote migration of excess water to the gluten network. Water absorption capacity (WAC) results for the flour blends at $10 \%$, $20 \%$, and $30 \%$ were in the range $60.43-62.10 \%, 61.03$ - $61.50 \%$, and 59.57 - $60.33 \%$, respectively, and negatively correlated with CFSL $(r=-0.652, p<0.05)$ suggesting that higher CFSL resulted in decreasing WAC, in part, due to large particle size of cassava flour with low water absorption capacity. There was a weak positive correlation between WAC and protein $(r=0.337, p<0.01)$, lipid $(r=0.359, p<0.01)$ and fibre $(r=0.356, p<0.01)$ contents. The high protein and fibre levels in wheat flours

Table 1: Moisture, protein, lipid, and amylose contents, and particle size of cassava flours from six cassava varieties grown in Zambia

\begin{tabular}{lllllll}
\hline Variety & Moisture (\%) & Protein $(\%)$ & Lipid $(\%)$ & Fibre $(\%)$ & Amylose $(\%)$ & Size $(\mu \mathrm{m})$ \\
\hline Bangweulu & $11.02(1.00)^{\mathrm{ab}}$ & $1.87(0.78)^{\mathrm{b}}$ & $0.40(0.04)^{\mathrm{bc}}$ & $0.60(0.49)^{\mathrm{b}}$ & $22.22(2.78)^{\mathrm{ab}}$ & $312.01(0.00)^{\mathrm{a}}$ \\
Katobamputa & $11.05(1.46)^{\mathrm{ab}}$ & $1.45(0.03)^{\mathrm{ab}}$ & $0.41(0.05)^{\mathrm{bc}}$ & $0.15(0.15)^{\mathrm{a}}$ & $26.95(2.30)^{\mathrm{b}}$ & $282.53(0.02)^{\mathrm{c}}$ \\
Mweru & $11.76 \pm(1.61)^{\mathrm{b}}$ & $1.78(0.28)^{\mathrm{ab}}$ & $0.59(0.18)^{\mathrm{cd}}$ & $0.05(0.06)^{\mathrm{a}}$ & $17.95(8.02)^{\mathrm{a}}$ & $250.43(0.03)^{\mathrm{b}}$ \\
Kariba & $11.18 \pm(0.72)^{\mathrm{ab}}$ & $1.43(0.41)^{\mathrm{ab}}$ & $0.63(0.06)^{\mathrm{d}}$ & $0.04(0.02)^{\mathrm{a}}$ & $16.04(1.16)^{\mathrm{a}}$ & $332.52(0.02)^{\mathrm{e}}$ \\
Kampolombo & $10.69 \pm(0.62)^{\mathrm{a}}$ & $1.58(0.15)^{\mathrm{ab}}$ & $0.32(0.20)^{\mathrm{ab}}$ & $0.03(0.02)^{\mathrm{a}}$ & $18.47(7.30)^{\mathrm{a}}$ & $334.43(0.01)^{\mathrm{e}}$ \\
Chila & $10.43 \pm(0.37)^{\mathrm{a}}$ & $1.21(0.09)^{\mathrm{a}}$ & $0.15(0.04)^{\mathrm{a}}$ & $0.15(0.05)^{\mathrm{a}}$ & $16.15(3.88)^{\mathrm{a}}$ & $278.49(0.00)^{\mathrm{c}}$ \\
Wheat (control) & $13.37 \pm(0.15)^{\mathrm{d}}$ & $11.03(0.27)^{\mathrm{c}}$ & $1.72(0.16)^{\mathrm{c}}$ & $2.90(0.10)^{\mathrm{c}}$ & $20.83(0.45)^{\mathrm{ab}}$ & $206.67(6.81)^{\mathrm{a}}$ \\
\hline
\end{tabular}

All values are means of three replications. Data in the parenthesis are the standard deviations. Within the same column, the values with different letters are significantly different at $p<0.05$ by LSD test. 
Table 2: Moisture, water absorption capacity, and crude gluten contents of cassava-wheat flour blends

\begin{tabular}{|c|c|c|c|c|}
\hline Variety & CFSL (\%) & Moisture (\%) & Water absorption capacity (\%) & Gluten (\%) \\
\hline Bangweulu & 10 & $13.23(0.31)^{\mathrm{ab}}$ & $60.43(1.62)^{\mathrm{abcd}}$ & $10.41(0.04)^{\mathrm{de}}$ \\
\hline Katobamputa & 10 & $13.47(0.06)^{\mathrm{bcd}}$ & $62.10(0.10)^{\mathrm{e}}$ & $11.25(0.01)^{\mathrm{ef}}$ \\
\hline Mweru & 10 & $13.27(0.15)^{\mathrm{ab}}$ & $61.53(0.20)^{\mathrm{e}}$ & $10.41(0.02)^{\mathrm{de}}$ \\
\hline Kariba & 10 & $13.37(0.06)^{\mathrm{abc}}$ & $61.37(1.19)^{\mathrm{cde}}$ & $11.26(0.01)^{\mathrm{ef}}$ \\
\hline Kampolombo & 10 & $13.27(0.05)^{\mathrm{ab}}$ & $61.63(0.46)^{\mathrm{e}}$ & $11.28(0.01)^{\mathrm{ef}}$ \\
\hline Chila & 10 & $13.27(0.06)^{\mathrm{ab}}$ & $61.57(0.30)^{\mathrm{e}}$ & $11.28(0.01)^{\mathrm{ef}}$ \\
\hline Bangweulu & 20 & $13.13(0.15)^{\mathrm{a}}$ & $61.10(0.87)^{\text {bcde }}$ & $9.56(0.02)^{\mathrm{cd}}$ \\
\hline Katobamputa & 20 & $13.83(0.06)^{\mathrm{ef}}$ & $61.40(0.20)^{\mathrm{cde}}$ & $8.62(0.87)^{\mathrm{bc}}$ \\
\hline Mweru & 20 & $13.27(0.21)^{\mathrm{ab}}$ & $61.03(1.00)^{\text {bcde }}$ & $8.67(0.85)^{b c}$ \\
\hline Kariba & 20 & $13.67(0.06)^{\text {cde }}$ & $61.53(0.50)^{\mathrm{e}}$ & $7.77(0.87)^{\mathrm{ab}}$ \\
\hline Kampolombo & 20 & $13.23(0.15)^{\mathrm{av}}$ & $61.50(0.20)^{\mathrm{de}}$ & $12.15(0.03)^{\mathrm{fg}}$ \\
\hline Chila & 20 & $13.37(0.15)^{\mathrm{abc}}$ & $61.37(0.55)^{\text {cde }}$ & $10.40(0.02)^{\mathrm{de}}$ \\
\hline Bangweulu & 30 & $13.40(0.20)^{\mathrm{abcd}}$ & $59.90(0.53)^{\mathrm{a}}$ & $8.66(0.02)^{b c}$ \\
\hline Katobamputa & 30 & $13.67(0.59)^{\mathrm{cde}}$ & $59.57(0.06)^{\mathrm{a}}$ & $8.06(1.01)^{\mathrm{bc}}$ \\
\hline Mweru & 30 & $13.47(0.15)^{\mathrm{ab}}$ & $59.67(0.35)^{\mathrm{a}}$ & $6.92(0.87)^{\mathrm{a}}$ \\
\hline Kariba & 30 & $14.00(0.10)^{\mathrm{f}}$ & $60.17(0.15)^{\mathrm{ab}}$ & $6.88(0.86)^{\mathrm{a}}$ \\
\hline Kampolombo & 30 & $13.43(0.16)^{\mathrm{abcd}}$ & $60.33(0.58)^{\mathrm{abc}}$ & $9.23(0.51)^{\mathrm{c}}$ \\
\hline Chila & 30 & $13.70(0.10)^{\mathrm{def}}$ & $60.07(0.90)^{\mathrm{ab}}$ & $10.36(0.01)^{\mathrm{de}}$ \\
\hline Wheat & 100 & $13.37(0.15)^{\mathrm{abc}}$ & $61.70(0.61)^{\mathrm{e}}$ & $13.00(0.87)^{\mathrm{g}}$ \\
\hline
\end{tabular}

All values are means of three replications. Data in the parenthesis are the standard deviations.

Within the same column, the values with different letters are significantly different at $p<0.05$ by LSD test. CFSL $=$ Cassava flour substitution level

are significant contributors toward water absorption. The protein contents were generally very low in cassava with insignificant difference among the cassava varieties $(p>0.05)$. The fibre contents of the cassava varieties $(\leq 0.6 \%)$ were low compared to wheat flours $(2.9 \%)(p<0.05)$ and hence the contribution of cassava fibre to WAC was likely low. Nevertheless, the difference in fibre content can bring a difference in water absorption of wheat flours. A study by Struck et al. (2018) found that addition of almond fibre significantly reduced WAC of wheat flour. In a similar study on potato-wheat flour, higher protein contents increased WAC of wheat flour (Sarker et al., 2008). The WAC of the flour blends showed significant correlations with gluten content $(r=0.595, \mathrm{p}>0.05)$, an indication that high gluten content resulted in a high WAC. There was a negative correlation of WAC with flour particle size $(r=-0.264, p<0.001)$, which indicates that smaller particle size had higher water hydration capacity.

\subsection{STICKINESS CHARACTERISTIC}

Table 3 shows results for stickiness and peak positive force of unleavened, leavened and frozen leavened doughs. Table 4 show results for work of adhesion and peak positive area of unleavened, leavened and frozen leavened doughs.

The stickiness parameters include work of adhesion, peak positive force and positive area. The work of adhesion is generated during compression. The bonding between adhesive (dough) and adhered (probe surface) is essential for stickiness, however, the mechanism of failure of this bond is equally important (Fig. 1). The clear failure of adhesive and the adhered surface is termed adhesive failure while the failure within the adhesive with residue on the adhered surface is known as cohesive failure (Kilcast and Roberts, 1998;Adhikari et al., 2001). The strength of the dough is influenced by covalent or ionic bonding developing (Dobraszczyk, 1997) upon hydration and kneading. 


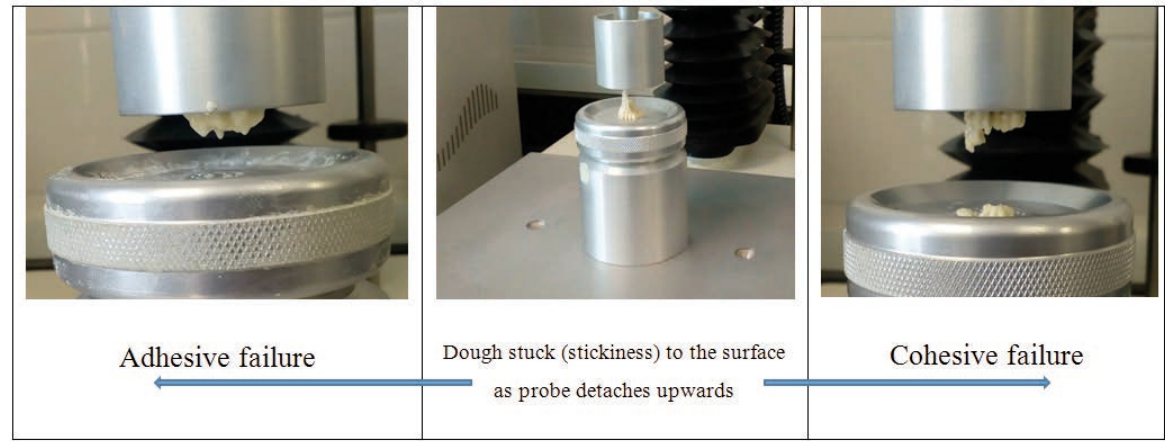

Figure 1: Schematic presentation of stickiness and observed mechanism of failure between the dough (adhesive) and probe surface (adhered)

\subsection{STICKINESS OF UNLEAVENED DOUGH}

The peak positive force of unleavened dough were in the range $0.44-0.77 \mathrm{~N}, 0.61-1.26 \mathrm{~N}$, and $0.57-1.20 \mathrm{~N}$, at 10, 20 and $30 \%$ cassava flour level, respectively (Table $3)$, and increased significantly $(p<0.05)$ with increase in CFSL $(r=0.678, p<0.05)$. The peak positive force is the maximum force required to pull a compression surface (probe) from a sample after the compression. Doughs with stickiness above the $1 \mathrm{~N}$ value were characteristic of dough handling difficulties. The work of adhesion of the unleavened dough were ranged from -35.40 to -90.70 g. s, -68.40 to -90.50 g.s, and -33.10 to -90.30 g.s, at 10, 20 and $30 \%$ CFSL, respectively. The control sample $(-72.50 \pm 10.31$ g.s $)$ significantly $(p<0.05)$ increased at higher cassava flour levels. The work of adhesion correlated positively with force $(\mathrm{r}=0.515, p<0.05)$ and weak positive with gluten $(r=0.137, p<0.0001)$. The adhesion is influenced by cohesion forces which are governed by chemical bonds due to crosslinking of the polymers, glutenin and gliadins within the dough resulting in cohesive and viscoelastic gluten (Guo et al., 2018). The positive area for wheat sample in unleavened dough was $0.03 \pm 0.01$ N.s, and increased with increase in CFSL ( $\mathrm{r}$ $=0.321, p<0.05)$. Positive area exhibited strong positive correlation with both stickiness and peak positive force $(\mathrm{r}=0.779, p<0.05)$ and work of adhesion $(\mathrm{r}=0.710$, $p<0.05$ ). This means that area of displacement is larger in sticky doughs, and may result into adhesive and cohesive failure. The peak positive area is the maximum area of displacement in the dough as the probe (contact surface) detaches upwards from the surface of the dough (Fig 1).

The unleavened dough of flour blends had stickiness in the range $34.14-74.10 \mathrm{~g}, 49.58-77.20 \mathrm{~g}$, and 57.91 - $122.17 \mathrm{~g}$, at 10, 20 and $30 \%$ CFSL, respectively, and increased significantly with CFSL $(r=0.678, p<0.05)$. The wheat sample exhibited stickiness of $42.63 \mathrm{~g}$ and was observed to increase with increase in CFSL. Stickiness correlated positively with work of adhesion $(\mathrm{r}=0.515$, $p<0.05)$, peak force $(\mathrm{r}=1.000, p<0.05)$ and positive area $(\mathrm{r}=0.779, p<0.05)$ (Table 5). This implies that unleavened sticky doughs were associated with higher work of adhesion. Higher stickiness values were characterized with high positive forces. The stickiness of unleavened dough correlated negatively with gluten $(\mathrm{r}=-0.445$, $p<0.01)$, protein $(\mathrm{r}=-0.592, p<0.05)$, WAC $(\mathrm{r}=-0.437$, $p<0.01)$, and positively with flour particle size $(\mathrm{r}=0.412$, $p<0.05$ ) suggesting that unleavened doughs with higher gluten and protein content, and high hydration capacity gave lower stickiness values. The larger flour particle sizes hydrate slowly, thus limiting development of gluten structure resulting in high stickiness. High positive area values were characteristic of sticky doughs. Similar was observed in a related study by Amonsou et al. (2013) on adhesiveness of marama bean protein. The reduction in work of adhesion and peak area resulted in decreased stickiness. The differences in varieties could be attributed to variations in amylose contents. The unleavened dough stickiness exhibited negative correlation with amylose contents $(\mathrm{r}=-0.340, p<0.01)$. This suggests that higher amylose varieties were less sticky.

\subsection{STICKINESS OF LEAVENED DOUGH}

The peak positive force (PPF) of leavened dough ranged $0.25-0.34 \mathrm{~N}, 0.21-0.50 \mathrm{~N}$, and $0.25-0.82 \mathrm{~N}$, at 10, 20 and $30 \%$ CFSL, respectively. The positive force for the control sample was $0.19 \mathrm{~N}$, and was observed to increase with CFSL, and was lower than the positive force of the unleavened dough. The work of adhesion (WA) increased in the leavened dough ranging from -130.20 to -194.40 g.s, -123.90 to -210.40 g.s, and -72.80 to -234.80 g.s, at 10,20 , and $30 \%$ CFSL, respectively. The WA for the wheat was -167.2 g.s, and increased with increasing CFSL. WA for leavened dough had positive correlation $(\mathrm{r}=0.287, p<0.001)$ with gluten (Table 5). 


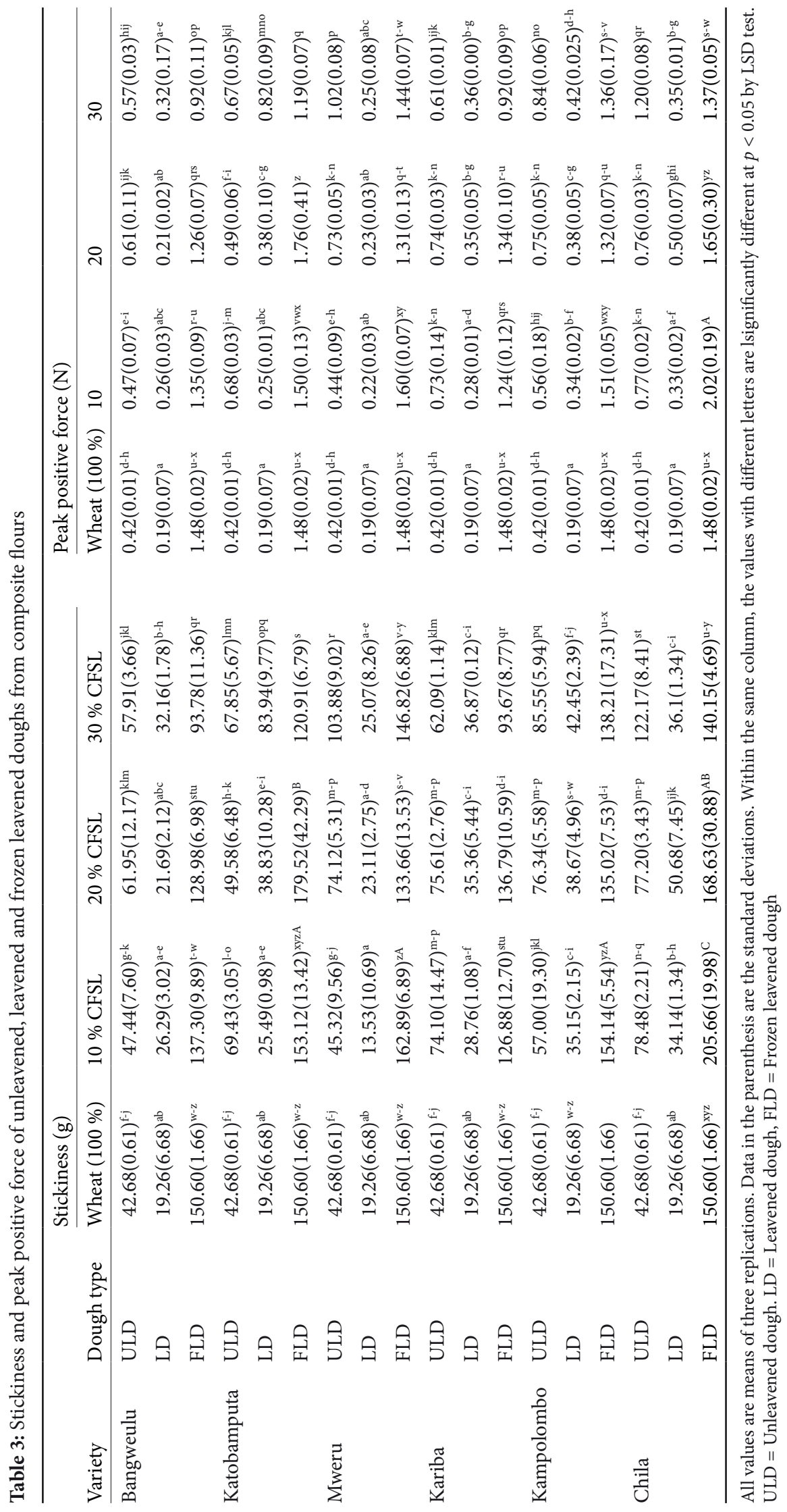




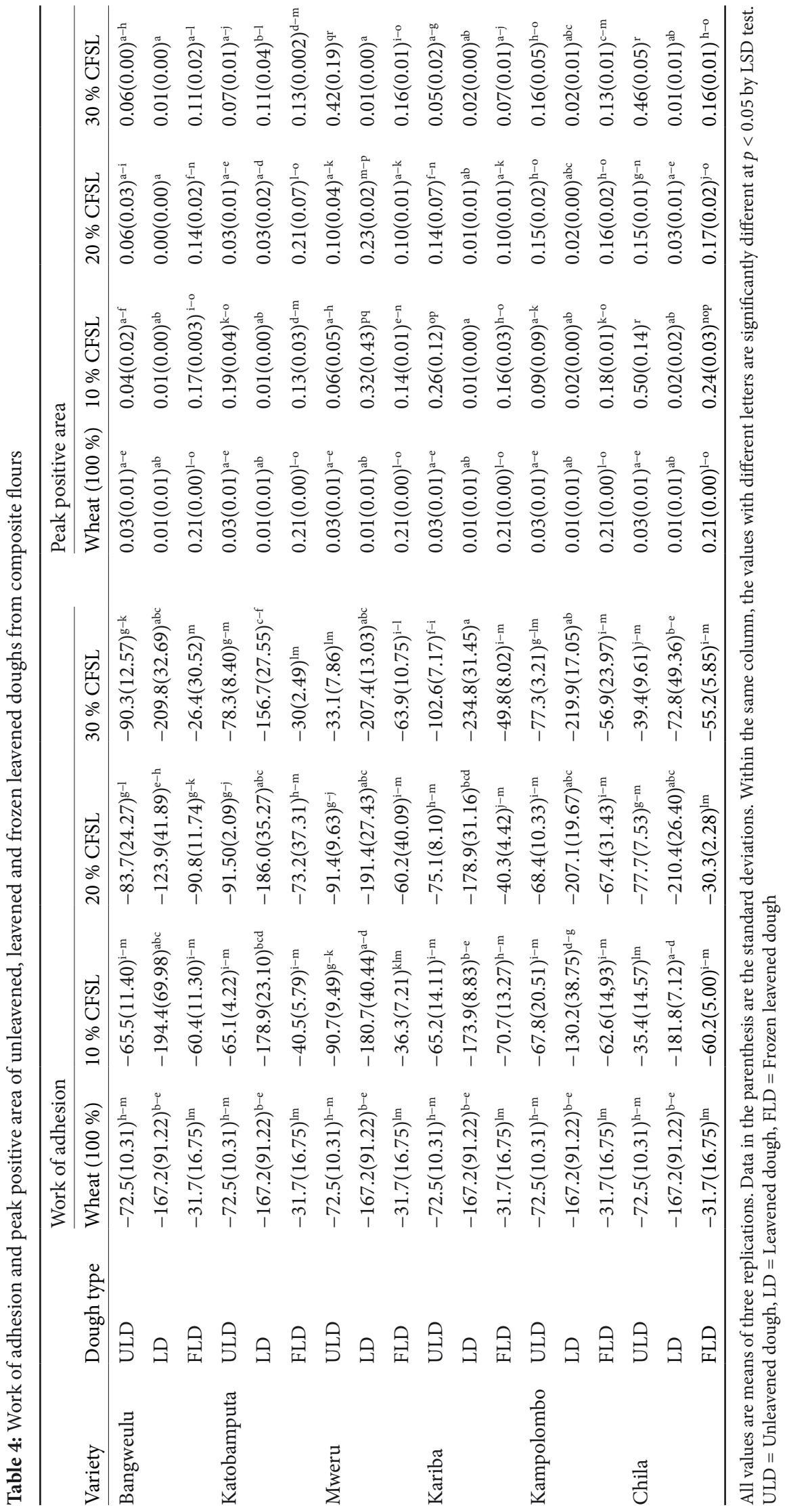


The peak positive area (PPA) of wheat sample had lower value $(0.01 \pm 0.01 \mathrm{~N} . \mathrm{s})$ than that of wheat sample from unleavened dough. The stickiness of the leavened dough were in the range $13.53-35.15 \mathrm{~g}, 21.69-50.68 \mathrm{~g}$, and $25.07-83.94$ g, at 10,20 and $30 \%$ CFSL, respectively, and varied significantly $(p<0.05)$ according to CFSL $(\mathrm{r}=0.578, p<0.05)$. The wheat sample had stickiness of $19.26 \pm 6.68 \mathrm{~g}$ which increased with increasing CFSL. The stickiness of leavened dough negatively correlated with protein $(\mathrm{r}=-0.465, p<0.05)$. In a related study, Gujral et al. (2018) reported that blending gluten-free flours with wheat resulted in protein weakening due to increased starch-starch, and starch-protein interaction resulting in low level of gluten formation. The gluten content showed negative correlation with stickiness in leavened dough $(\mathrm{r}=-0.457, p<0.01)$ similar to that observed in unleavened dough $(\mathrm{r}=-0.445, p<0.01)$. The stickiness increased with reduced gluten contents in flour blends in both unleavened and leavened doughs. High CFSL were associated with low gluten contents and yielded high stickiness. The negative correlation of stickiness with WAC in leavened $(\mathrm{r}=-0.434, p<0.01)$ was similar with WAC in unleavened $(\mathrm{r}=-0.437, p<0.01)$ doughs. This implies that higher WAC produced less sticky doughs. Similar was observed in the work of Amonsou et al. (2013) in which pure gluten isolates were characterized with lower forces of adhesion (low stickiness) as moisture content increased. The amylose contents in the leavened dough did not influence stickiness $(r=0.078$, $p>0.01$ ). This may suggest that addition of leavening ingredients reduced the influence of amylose contents on stickiness. In the current study, the amylose contents of the flours were classified as normal or regular starches, and have been reported to be highly susceptible to enzymatic hydrolysis (Adefegha et al., 2018). The positive correlation of stickiness with flour particle size in leavened $(r=0.423, p<0.01)$ was similar with flour particle size in unleavened $(\mathrm{r}=0.412, p<0.01)$ doughs. There was reduction in stickiness upon inclusion of ingredients (yeast, salt, fat and sugar). The stickiness trend was unleavened $>$ leavened dough. The development of dough is important in baking since it combines the ingredients and develops a unique viscoelastic gluten network. Chen et al. (2018) reported that salt increases dough mixing resistance, and decreases dough stickiness during processing as higher levels of salt induced stronger gluten interactions via sulfhydryl-disulfide cross-linking. Salt has been identified as an ingredient in the dough that influences the level of protein-protein interactions and strength of the gluten network by changing the level of gluten hydration. Salt shields around the protein surface and thus induce charge on amino acids on the protein's surface, thus reducing the thickness of the electric dou- ble layer, and strengthening gluten interactions, which would subsequently yield a stronger network (Avramenko et al., 2018). Fat enhances dough plasticity (Mert and Demirkesen, 2016), softens and improve smoothness of the dough (Öztürk and Ova, 2018) which would probably contribute to reduced surface tension between probe surface and dough. Adhesion is negligibly small in smooth surfaces (McFarlane and Tabor, 1950; Liu et al., 2018). Dough stickiness may result in chewy bread that adheres to the mouth. Often the dough would seem unbaked, and would thus contribute to decreased consumer acceptance (Caramanico et al., 2018). Grausgruber et al. (2003) classified sticky and non-sticky dough as: stickiness greater than $90 \mathrm{~g}$ results in sticky dough, and less than $80 \mathrm{~g}$ produces non-sticky dough.

\subsection{STICKINESS OF FROZEN LEAVENED DOUGH}

The peak positive force (PPF) for frozen dough showed higher levels of peak force in the range 1.24 $2.02 \mathrm{~N}, 1.26-1.65 \mathrm{~N}, 0.92-1.44 \mathrm{~N}$ at 10,20 and $30 \%$ CFSL, respectively, and significantly decreased with increase in CFSL $(r=-0.409, p<0.01)$. The PPF for the wheat sample was $1.48 \pm 0.02 \mathrm{~N}$. The forces were generally higher at 10 and $20 \%$, and lower at $30 \%$ CFSL. These variations were due to differences in gluten content. The PPF showed weak positive correlation with gluten $(\mathrm{r}=0.325, p<0.01)$, implying that strong gluten content doughs would require higher forces to detach from the adhering surfaces. The WA for frozen dough ranged from -36.30 to $-70.70,-30.30$ to -90.80 and -26.40 to -63.90 g.s, at 10,20 and $30 \%$ CFSL, respectively, and decreased significantly $(p<0.001)$ with increase in CFSL. The WA value $(31.7 \pm 16.75$ g.s) for wheat sample was lower than those of unleavened and leavened doughs. This implies that probe surface would require small amount of work to adhere to sticky doughs (sticky doughs easily adheres to surfaces). There was significant $(p<0.05)$ increase of PPA in frozen dough compared to unfrozen leavened dough. This implies adhesive material (dough) displaced from the dough increased. The wheat sample for frozen dough exhibited higher PPA value $(0.21 \pm 00)$ and exhibited insignificant changes $(p>0.05)$ in flour blends.

There was significant increase in the stickiness of the frozen dough compared to unfrozen doughs. The stickiness was in the range $126.88-205.66 \mathrm{~g}, 128.98-$ $179.52 \mathrm{~g}$ and $93.67-146.82 \mathrm{~g}$, at 10,20 and $30 \%$ CFSL, respectively. The stickiness of wheat sample $(150 \pm 60 \mathrm{~g})$ decreased significantly $(r=-0.409, p<0.05)$ with increase in CFSL. Stickiness of frozen doughs was higher at $10 \%$ cassava flour level, and generally lower at subsequent blend ratios. This trend is opposite to that of unfrozen 


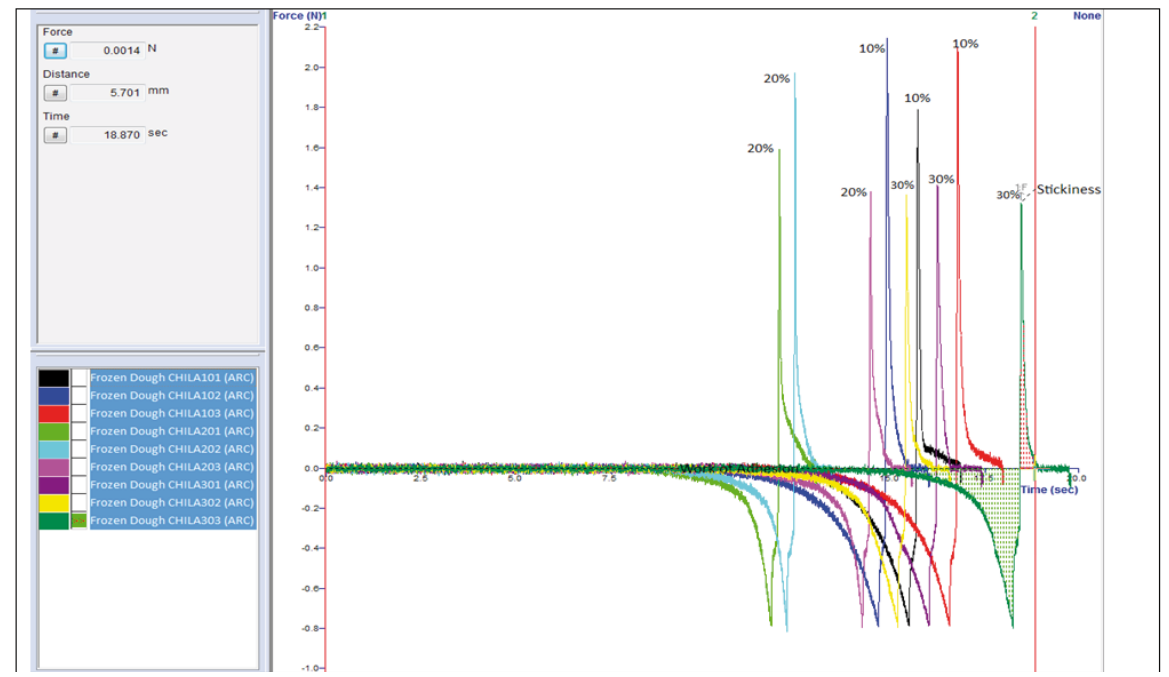

Figure 2: Typical curves for frozen dough of wheat-cassava blend flour at 10, 20 and $30 \%$ cassava flour concentration levels. Cassava variety: Chila

doughs, in which higher CFSL doughs gave lower stickiness. This variation could suggest that depolymerization of gluten during frozen storage generates low molecular mass compounds which are hydrophobic nature. During frozen storage, the water solidifies into ice through crystallization, and subsequent expansion of solid water can cause physical rupture of protein (disulfide) films, thus limiting protein-protein interactions leading to weakening of gluten. During thawing the ice melts and separates irreversibly away from the starch-gluten matrix which reduces interaction of water with hydration sites of gluten-starch system. Hence, the resulting water phase is in weak interaction with the gluten structure (Zhao et al., 2013;Ma et al., 2016). The unbound water probably might have contributed to increased adhesion. Similar was observed by Amonsou et al. (2013) as high moisture content doughs exhibited higher force of adhesion. Moreover, development of gluten structure is the function of disulphide bonds in glutenin and gliadins, and thus depleting disulphide bonds weakens the gluten matrix. The developed gluten matrix undergo deterioration exhibited through molecular changes during frozen storage (Wang et al., 2018). Zhao et al. (2013) reported free sulfhydryl groups increased in the wheat dough during frozen storage time, which indicated decrease of number of disulphide bonds. The higher peak stickiness (Fig 2) in low levels of cassava flour could be as the result of increased number of low molecular mass oligomers due to depolymerisation of glutenin which occurs via the breakage of interchain disulphide bonds, and thus weakening the viscoelasticity resulting in higher stickiness. Also, the decrease in stickiness at higher CFSL could be ascribed to high contents of starches in cassava flour with higher water binding capacity than wheat gluten.

\section{CONCLUSION}

The stickiness of wheat related blends are dependent on water absorption and gluten development. The stickiness in the unleavened and leavened doughs increased with increasing CFSL. The opposite was observed in the frozen dough in which the stickiness decreased with increasing cassava flour level. Cassava flour acted as diluent against gluten content in wheat, and caused excess water in the aqueous phase at higher CFSL. In the frozen dough, the deterioration of gluten might have led to increased unbound water leading to higher stickiness values at lower CFSL. The stickiness of unleavened dough decreased upon inclusion of ingredients. Therefore, leavened exhibited lower stickiness values than unleavened dough. The frozen dough would be recommended for re-kneading to re-develop the desired consistency with reduced stickiness. Future investigation should focus on the effect of dough improvers (ingredients) on the stickiness of frozen dough.

\section{REFERENCES}

AACC. (2011). AACC International, Approved methods of American Association of Cereal Chemists. 10th ed. ST. Paul, MN : AACC International.

AACCI. (2000). AACCI methods 10-10.03 (Optimized Straight-Dough Bread-Making Method). In: Approved 


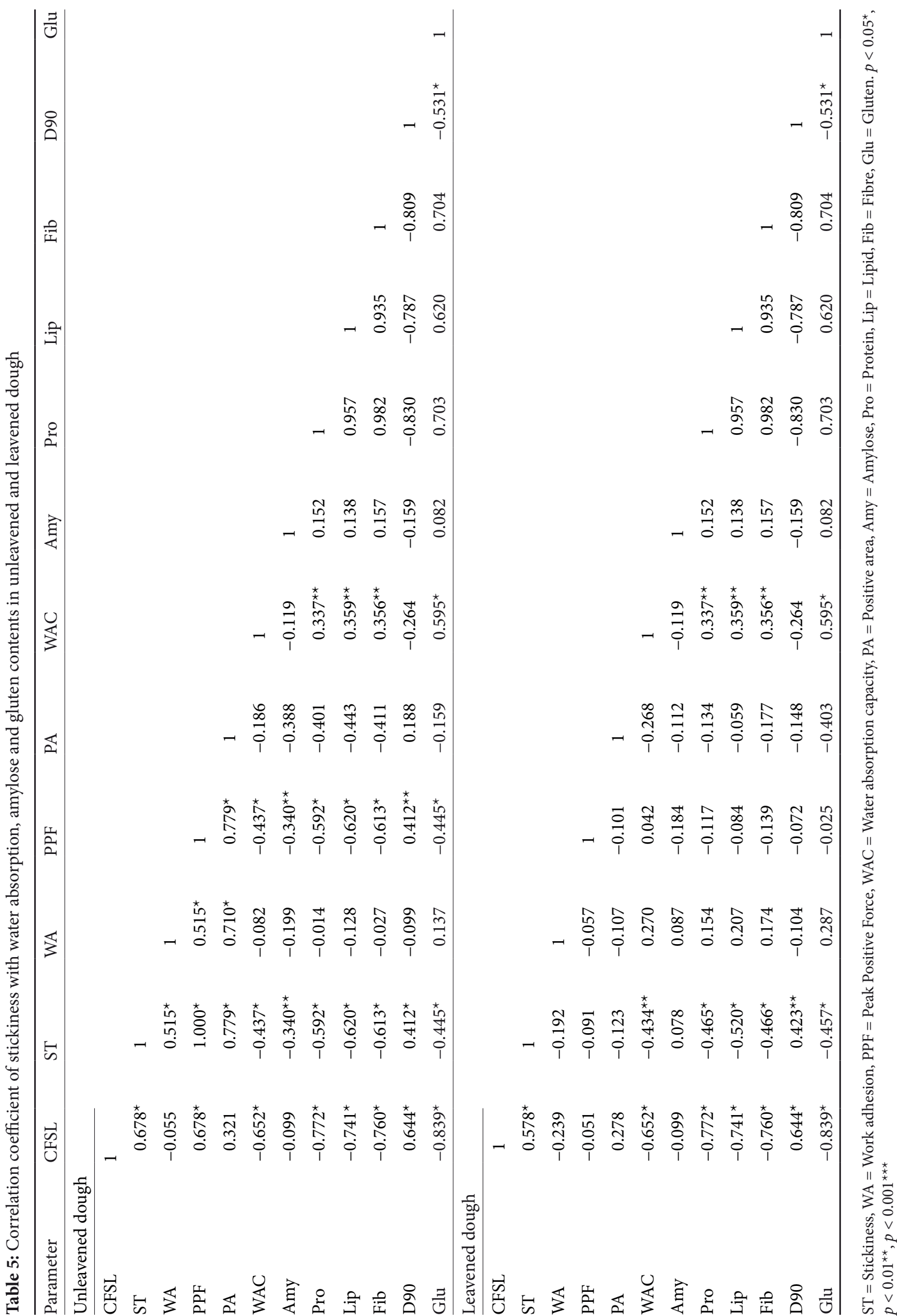




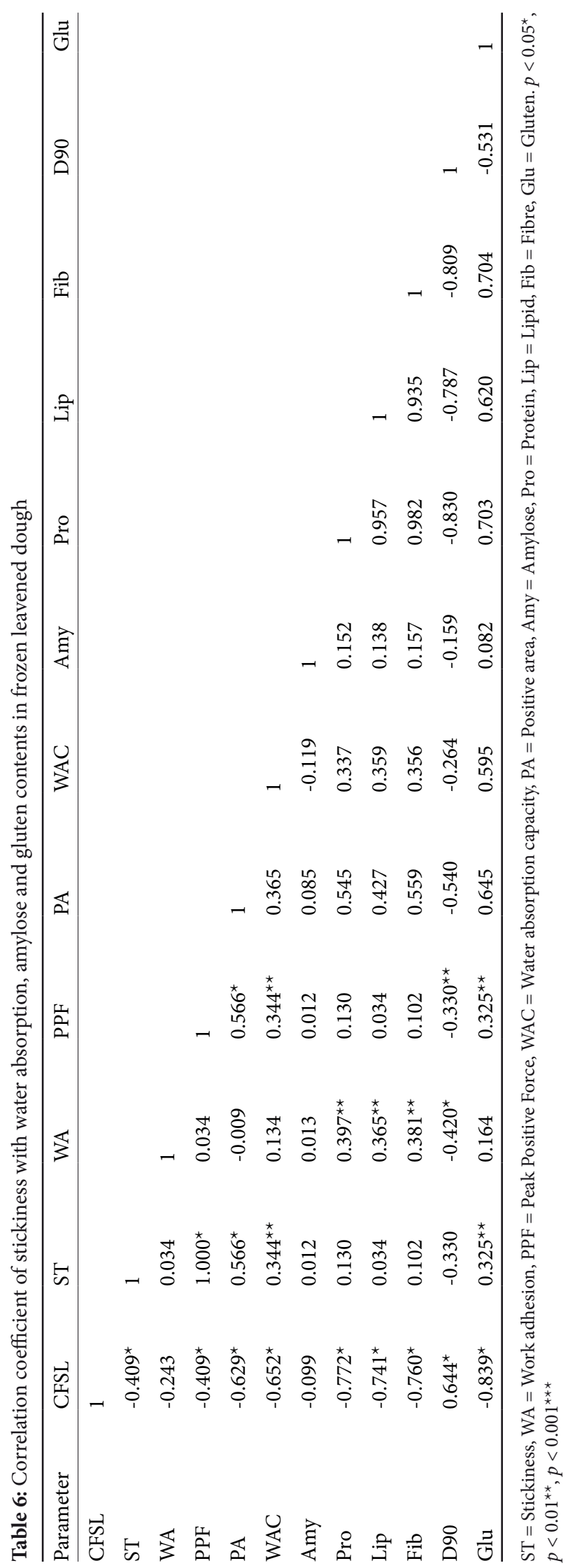

44 | Acta agriculturae Slovenica, 114/2 - 2019 
methods of American Association of Cereal Chemists. 10th ed. ST. Paul , MN : AACC International.

Aboaba, O and Obakpolor, E. (2010). The leavening ability of bakers yeast on dough prepared with composite flour (wheat/cassava). African Journal of Food Science, 4(6), 330-329.

Adefegha, SA, Olasehinde, TA and Oboh, G. (2018). Pasting alters glycemic index, antioxidant activities, and starchhydrolyzing enzyme inhibitory properties of whole wheat flour. Food Science \& Nutrition, 6(6), 1591-1600. https:// doi.org/10.1002/fsn3.711

Adhikari, B, Howes, T, Bhandari, B and Truong, V. (2001). Stickiness in foods: a review of mechanisms and test methods. International Journal of Food Properties, 4(1), 1-33. https://doi.org/10.1081/JFP-100002186

Amonsou, EO, Taylor, JR and Minnaar, A. (2013). Adhesive potential of marama bean protein. International Journal of Adhesion and Adhesives, 41, 171-176. https://doi.org/10.1016/j. ijadhadh.2012.11.002

Avramenko, N, Tyler, R, Scanlon, M, Hucl, P and Nickerson, M. (2018). The chemistry of bread making: The role of salt to ensure optimal functionality of its constituents. Food Reviews International, 34(3), 204-225. https://doi.org/10.1080 /87559129.2016.1261296

Botticella, E, Sestili, F, Sparla, F, Moscatello, S, Marri, L, Cuesta-Seijo, JA, Falini, G, Battistelli, A, Trost, P and Lafiandra, D. (2018). Combining mutations at genes encoding key enzymes involved in starch synthesis affects the amylose content, carbohydrate allocation and hardness in the wheat grain. Plant Biotechnology Journal, 16(10), 1723-1734. https://doi.org/10.1111/pbi.12908

Caramanico, R, Marti, A, Vaccino, P, Bottega, G, Cappa, C, Lucisano, $\mathrm{M}$ and Pagani, MA. (2018). Rheological properties and baking performance of new waxy lines: Strengths and weaknesses. LWT - Food Science and Technology, 88, 159164. https://doi.org/10.1016/j.lwt.2017.09.035

Chakrabarti, T, Poonia, A and Chauhan, AK. (2017). Process optimization of gluten free cookies using cassava flour. International Journal of Food Science and Nutrition, 2(5), 190195.

Chen, G, Ehmke, L, Sharma, C, Miller, R, Faa, P, Smith, G and Li, Y. (2018). Physicochemical properties and gluten structures of hard wheat flour doughs as affected by salt. Food Chemistry, 275, 569-576. https://doi.org/10.1016/j.foodchem.2018.07.157

Collar, C and Armero, E. (2018). Kinetics of in vitro starch hydrolysis and relevant starch nutritional fractions in heatmoisture treated blended wheat-based bread matrices: impact of treatment of non-wheat flours. European Food Research and Technology, 244(11), 1977-1984. https://doi. org/10.1007/s00217-018-3109-1

Dobraszczyk, B. (1997). The rheological basis of dough stickiness. Journal of Texture Studies,28(2), 139-162. https://doi. org/10.1111/j.1745-4603.1997.tb00108.x

dos Santos, TPR, Franco, CML, Demiate, IM, Li, X-H, Garcia, EL, Jane, J-l and Leonel, M. (2018). Spray-drying and extrusion processes: Effects on morphology and physicochemical characteristics of starches isolated from Peruvian carrot and cassava. International Journal of Biological Macromol- ecules, 118 Part A, 1346-1353. https://doi.org/10.1016/j. ijbiomac.2018.06.070

Eriksson, E, Koch, K, Tortoe, C, Akonor, P and Oduro-Yeboah, C. (2014). Evaluation of the physical and sensory characteristics of bread produced from three varieties of cassava and wheat composite flours. Food and Public Health, 4(5), 214-222.

Grausgruber, H, Hatzenbichler, E and Ruckenbauer, P. (2003). Analysis of repeated stickiness measures of wheat dough using a texture analyzer. Journal of Texture Studies, 34(1), 69-82. https://doi.org/10.1111/j.1745-4603.2003.tb01056.x

Gujral, HS, Sharma, B and Khatri, M. (2018). Influence of replacing wheat bran with barley bran on dough rheology, digestibility and retrogradation behavior of chapatti. Food Chemistry, 240, 1154-1160. https://doi.org/10.1016/j.foodchem.2017.08.042

Guo, X, Sun, X, Zhang, Y, Wang, R and Yan, X. (2018). Interactions between soy protein hydrolyzates and wheat proteins in noodle making dough. Food Chemistry, 245, 500-507. https://doi.org/10.1016/j.foodchem.2017.10.126

Hoseney, R and Smewing, J. (1999). Instrumental measurement of stickiness of doughs and other foods. Journal of Texture Studies, 30(2), 123-136. https://doi. org/10.1111/j.1745-4603.1999.tb00206.x

Kaushik, R, Kumar, N, Sihag, MK and Ray, A. (2015). Isolation, characterization of wheat gluten and its regeneration properties. Journal of Food Science and Technology, 52(9), 59305937. https://doi.org/10.1007/s13197-014-1690-2

Kilcast, D and Roberts, C. (1998). Perception and measurement of stickiness in sugar-rich foods. Journal of Texture Studies, 29(1),81-100. https://doi.org/10.1111/j.1745-4603.1998. tb00155.x

Král, M, Pokorná, J, Tremlová, B, Oštádalová, M, Trojan, V, Vyhnánek, T and Walczycka, M. (2018). Colored Wheat: Anthocyanin Content, Grain Firmness, Dough Properties, Bun Texture Profile. Acta Universitatis Agriculturae et Silviculturae Mendelianae Brunensis, 66(3), 685-690. https://doi. org/10.11118/actaun201866030685

Liu, C, Liu, L, Li, L, Hao, C, Zheng, X, Bian, K, Zhang, J and Wang, X. (2015). Effects of different milling processes on whole wheat flour quality and performance in steamed bread making. LWT-Food Science and Technology, 62(1), 310-318. https://doi.org/10.1016/j.lwt.2014.08.030

Liu, R, Sun, W, Zhang, Y, Huang, Z, Hu, H and Zhao, M. (2019). Preparation of starch dough using damaged cassava starch induced by mechanical activation to develop staple foods: Application in crackers. Food Chemistry, 271(1), 284-290. https://doi.org/10.1016/j.foodchem.2018.07.202

Liu, X, Wang, L, Qiao, Y, Sun, X, Ma, S, Cheng, X, Qi, W, Huang, W and Li, Y. (2018). Adhesion of liquid food to packaging surfaces: Mechanisms, test methods, influencing factors and anti-adhesion methods. Journal of Food Engineering, 228, 102-117. https://doi.org/10.1016/j.jfoodeng.2018.02.002

Ma, S, Li, L, Wang, X-x, Zheng, X-l, Bian, K and Bao, Q-d. (2016). Effect of mechanically damaged starch from wheat flour on the quality of frozen dough and steamed bread. Food Chemistry, 202, 120-124. https://doi.org/10.1016/j. foodchem.2016.01.075 
McFarlane, J and Tabor, D. (1997). Adhesion of solids and the effect of surface films. Proceedings of the Royal Society of London. Series A. Mathematical and Physical Sciences, 202(1069), 224-243. https://doi.org/10.1098/ rspa.1950.0096

Mert, B and Demirkesen, I. (2016). Evaluation of highly unsaturated oleogels as shortening replacer in a short dough product. LWT - Food Science and Technology, 68, 477-484. https://doi.org/10.1016/j.lwt.2015.12.063

Morante, N, Ceballos, H, Sánchez, T, Rolland-Sabaté, A, Calle, F, Hershey, C, Gibert, O and Dufour, D. (2016). Discovery of new spontaneous sources of amylose-free cassava starch and analysis of their structure and techno-functional properties. Food Hydrocolloids, 56(3), 383-395. https://doi. org/10.1016/j.foodhyd.2015.12.025

Öztürk, E and Ova, G. (2018). Evaluation of Cocoa Bean Hulls as a Fat Replacer On Functional Cake Production. Turkish Journal of Agriculture-Food Science and Technology, 6(8), 1043-1050. https://doi.org/10.24925/turjaf.v6i8.10431050.1934

Patwa, A, Malcolm, B, Wilson, J and Ambrose, KR. (2014). Particle size analysis of two distinct classes of wheat flour by sieving. Transactions of the American Society of Agricultural and Biological Engineers, 57(1), 151-159. https://doi. org/10.13031/trans.57.10388

Ribeiro, M, Nunes, FM, Rodriguez-Quijano, M, Carrillo, JM, Branlard, G and Igrejas, G. (2018). Next-generation therapies for celiac disease: The gluten-targeted approaches. Trends in Food Science \& Technology, 75(6): 56-71. https:// doi.org/10.1016/j.tifs.2018.02.021

Sakhare, SD, Inamdar, AA, Soumya, C, Indrani, D and Rao, GV. (2014). Effect of flour particle size on microstructural, rheological and physico-sensory characteristics of bread and south Indian parotta. Journal of Food Science and Technology, 51(12), 4108-4113. https://doi.org/10.1007/s13197013-0939-5

Sangnark, A and Noomhorm, A. (2004). Chemical, physical and baking properties of dietary fiber prepared from rice straw. Food Research International, 37(1), 66-74. https://doi. org/10.1016/j.foodres.2003.09.007

Sarker, MZI, Yamauchi, H, Kim, S-J, Matsumura-Endo, C, Takigawa, S, Hashimoto, N and Noda, T. (2008). A farinograph study on dough characteristics of mixtures of wheat flour and potato starches from different cultivars. Food Sci- ence and Technology Research, 14(2), 211-216. https://doi. org/10.3136/fstr.14.211

Sissons, M and Smit, J. (2018). Small-scale methods to assess the gluten properties of durum wheat. Cereal Chemistry, 95(3), 456-468. https://doi.org/10.1002/cche.10048

Stone, AK, Lam, RS, Hopkins, EJ, Hucl, P, Scanlon, MG and Nickerson, MT. (2018). Effect of organic acids and $\mathrm{NaCl}$ on the rheological properties of dough prepared using Pembina and Harvest CWRS wheat cultivars. Cereal Chemistry, 95(3), 478-485. https://doi.org/10.1002/cche.10050

Struck, S, Straube, D, Zahn, S and Rohm, H. (2018). Interaction of wheat macromolecules and berry pomace in model dough: Rheology and microstructure. Journal of Food Engineering, 223(4), 109-115. https://doi.org/10.1016/j.jfoodeng.2017.12.011

Tester, RF, Karkalas, J and Qi, X. (2004). Starch-composition, fine structure and architecture. Journal of Cereal Science, 39(2), 151-165. https://doi.org/10.1016/j.jcs.2003.12.001

Villanueva, M, Pérez-Quirce, S, Collar, C and Ronda, F. (2018). Impact of acidification and protein fortification on rheological and thermal properties of wheat, corn, potato and tapioca starch-based gluten-free bread doughs. LWT - Food Science and Technology, 96, 446-454. https://doi.org/10.1016/j. lwt.2018.05.069

Wang, N, Hou, GG and Dubat, A. (2017). Effects of flour particle size on the quality attributes of reconstituted wholewheat flour and Chinese southern-type steamed bread. LWT - Food Science and Technology, 82, 147-153. https:// doi.org/10.1016/j.lwt.2017.04.025

Wang, P, Zou, M, Gu, Z and Yang, R. (2018). Heat-induced polymerization behavior variation of frozen-stored gluten. Food Chemistry, 255, 242-251. https://doi.org/10.1016/j. foodchem.2018.02.047

Zadeike, D, Jukonyte, R, Juodeikiene, G, Bartkiene, E and Valatkeviciene, Z. (2018). Comparative study of ciabatta crust crispness through acoustic and mechanical methods: Effects of wheat malt and protease on dough rheology and crust crispness retention during storage. LWT - Food Science and Technology, 89, 110-116. https://doi.org/10.1016/j. lwt.2017.10.034

Zhao, L, Li, L, Liu, G-q, Chen, L, Liu, X, Zhu, J and Li, B. (2013). Effect of freeze-thaw cycles on the molecular weight and size distribution of gluten. Food Research International, 53(1), 409-416. https://doi.org/10.1016/j.foodres.2013.04.013 